\title{
土木学会論文報告集
}

第 325 号・1982 年 9 月

【論

文】

\section{鉄道線路における噴泥発生機構の基礎的研究 \\ FUNDAMENTAL STUDY ON THE PROCESS OF MUDPUMPING \\ IN THE RAILWAY TRACK}

\author{
山田幹 雄*.小野 一 良** \\ By Mikio YAMADA and Kazuyoshi ONO
}

\section{1. まえがき}

軟弱な粘土層の上に敷設された鉄道線路は, 列車通過 による繰り返し荷重によって道床砂利がしだいに粘土層 一圧入され, 粘土は道床砂利の間幥やまくらぎの周辺を 通って上昇する．地下水位の高いとき，または降雨によ って多量の水が供給されたときには, 列車通過時にまく らぎが沈下するとともに，まくらぎ下の粘土が泥水とな って道床表面に噴き上がることがある.この現象を噴泥 といっている.

噴泥を生じた場合には，それだけ道床砂利が路盤内に 圧入されたことになり，たとえ見掛け上レール面におけ る高低の変化はわずかでも，まくらぎ下面と道床面との 間に空隚を生じ, 列車の円滑な走行を妨げる.さらに, 道床砂利を補充し, 道床を突き固めるのに多大の労力と 費用が費やされる.

以上に述べた噴泥を根本的に防止するには，路盤の表 層土を噴泥を生じない土と置き換えればよいが，列車を 運行しながら路盤土を置換することは容易ではない.し たがって, 線路を敷設する当初からよい土を路盤の表層 土として使用すべきである．国鉄では，東海道新幹線の 建設を契機として在来の線路の不良路盤の実態を調查 し，噴泥を生じない土としては液性限界が $35 \%$ 以下で あること，その他の条件を指示している(1),2). また， す でに開業している区閒で噴泥を生じている場合に対処す

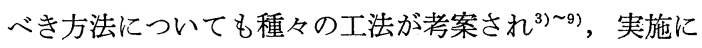
移されている.

このように，噴泥の実態とその防止工法に関しては従 来多くの調査と研究がなされ, その効果もあがっている が，噴泥の端緒ともいうべき道床砂利が粘土層へ圧入さ れる機構については，これまでにあまり解明されていな

* 学生員 工修 金沢工業大学大学院博士課程 土木工学専攻

** 正会員 工博 金沢工業大学教授 土木工学科
かった. 著者の 1 人は, かつてこの問題を解明する手掛 かりとして, 円筒容器の中に粘土を入れ, その上に砕石 砂利の層を置き, 繰り返して荷重を加えて砂利層の沈下 の進行を測定したことがあった ${ }^{10), 11)}$ 。この報告におい ては, 手動ジャッキによって圧力を加え, また最高, 最 低荷重において 30 秒ずつの保持時間をおいたため荷重 変動の周期が長く, 繰り返し回数の最高も200回に限ら れていたが, 粘土の含水比が液性限界よりわずかに少な いある限界值を越えたときに沈下の進行が急に大きくな ること, 沈下の進行が繰り返し回数の平方根に比例する こと, また沈下の進行が砕石の粒径に関連をもつことを 述べた.しかし，この実験では荷重変動の周期があまり にも長く，実際の鉄道線路の路盤に加わる荷重状態とは 異なり,また繰り返し回数も少なかったので, 振動疲労 試験機を用いて新たに実験を行い，その研究の成果につ いて数回の発表を行った ${ }^{12) \sim 14)}$.

以上の研究と並行して, 鉄道技術研究所でも現場にお ける噴泥の実態調査および実験室における模型実験が行 われている. その一つとして直径 $50 \mathrm{~cm}$ の円筒容器の中 に厚さ $20 \mathrm{~cm}$ の路盤を置き,この上に直径 $19 \mathrm{~mm}$ の鋼 球を 4 段重ねに置いて, 振動数 $11 \mathrm{~Hz}$ の繰り返し荷重を 加えたときの鋼球の沈下を測定した結果が報告されてい る ${ }^{15)}$.この研究においては, 荷重の大きさおよび路盤の 含水比を 3 段階に変えて実験がなされているが，比較的 低い含水比において大きな沈下の進行が 記録されてい る.

また，実際の鉄道線路に近い状態で路盤の上に道床砂 利およびまくらぎを重ねて繰り返し何重を加えたとき に, 道床砂利が路盤内に圧入される過程についての研究 が行われている ${ }^{16)}$. この研究においては, 路盤面は道床 砂利より圧力を受けて下方および側方への流動を生じ, その後泥土が砂利層中を上昇してまくらぎ下面に達する ようである.

以上に述べた研究と比べて本論文では, 粘土層の含水 
比を広い範囲で変動し, 道床面沈下の進行と含水比との 関連を明らかにしたこと，また繰り返し荷重の振動数を 各種の段階に変化して, 振動数との関連について研究を 進めたことに特徴がある.

\section{2. 実験方法および試料の性質}

\section{(1) 実験方法}

a) 試験装置

走行する列車から伝達される荷重を受けて, 道床砂利 が路盤内に圧入される過程を実験室内で再現するため に, 図一1 および写真一1 に示すような装置を用いた. 図に示すように, 直径 $50 \mathrm{~cm}$, 高さ $40 \mathrm{~cm}$ の円筒容器の

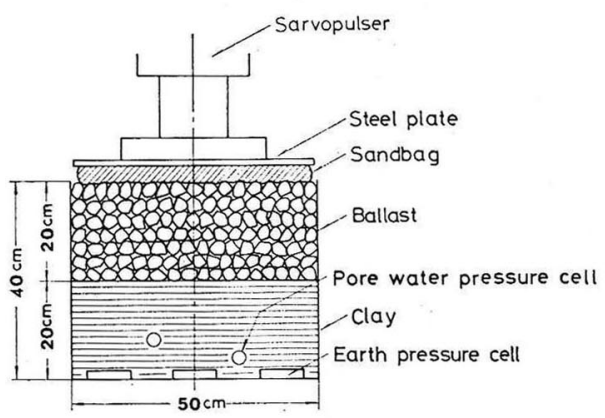

図一1 噴泥発生装置

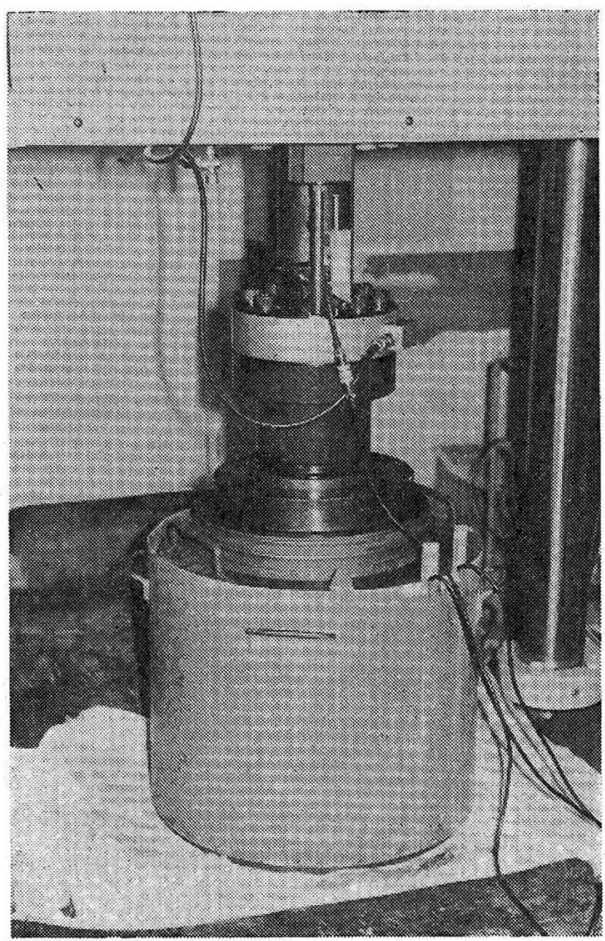

写真一1 試 験 装 置
中に，所定の含水比となるように 練り混ぜた粘土を 20 $\mathrm{cm}$ の高さに詰め, その上に砕石を $20 \mathrm{~cm}$ の厚さに置い た.この上から振動疲労試験機を用いて最初に静荷重を 加え, 続いて正弦波繰り返し荷重を加えた. 荷重が道床 面へ均一に分布するように, 試験機の耐圧盤と道床面と の間には厚さ $5 \mathrm{~cm}$ の砂袋を入れた. また，粘土層の表 面で容器の壁面と接する部分には布を置き, 道床砂利が 圧入する際に粘土が壁面に沿って上昇するのを防いだ.

容器の底部には土圧計を配置して, 粘土層に伝達される 圧力を測定した. 特に, 練り混ぜたときの飽和度がほぼ 100\%の粘土層には, 間隚水圧計を埋め込んだ.

静荷重および繰り返し荷重を加えている間の道床面の 沈下は, 試験機のラムの上下位置が計器盤にディジタル 表示されるので, これを読み取ると同時に変位計によっ て確認した．変位計，土圧計㧍よび間隚水圧計の指示值 はオシログラフに記録した.

b) 荷重および振動数

道床面に加える荷重は, 静的の場合にも繰り返しの場 合にも $3 \mathrm{tf}(29.4 \mathrm{kN})$ または $5 \mathrm{tf}(49 \mathrm{kN})$ とした.こ の荷重が砂利層を通して粘土層へ一様に伝達されると仮 定すれば, 粘土層中の圧力は $1.53 \mathrm{kgf} / \mathrm{cm}^{2}(150 \mathrm{kPa})$ ま たは $2.55 \mathrm{kgf} / \mathrm{cm}^{2}(250 \mathrm{kPa})$ となる．しかしながら土圧 計の記録によれば，荷重 $3 \mathrm{tf}(29.4 \mathrm{kN})$ の場合には 0.8 $\sim 1.1 \mathrm{kgf} / \mathrm{cm}^{2}(78 \sim 108 \mathrm{kPa}), \quad 5 \mathrm{tf}(49 \mathrm{kN})$ の場合には $1.4 \sim 1.7 \mathrm{kgf} / \mathrm{cm}^{2}(137 \sim 167 \mathrm{kPa})$ の圧力となった. これ は道床面に加えた荷重の 30 50\% が, 道床砂利と円筒 容器の壁面との摩擦によって消費されたことになる、い ま車両の軸重を. $16 \mathrm{tf}(156.8 \mathrm{kN})$ とするとき, $50 \mathrm{~kg}$ レ 一ル敷設, $25 \mathrm{~m}$ 当たりまくらぎ 41 本, 道床厚さ $25 \mathrm{~cm}$ の軌道において，まくらぎ直下の路盤面の受ける圧力を Boussinesq の式を用いて計算すれば $0.75 \mathrm{kgf} / \mathrm{cm}^{2}(74$ $\mathrm{kPa})$ となる. したがって, 道床面に $3 \mathrm{tf}(29.4 \mathrm{kN})$ の荷 重を加えることは，レール中間部において路盤が受ける 圧力にほぼ等しいとみることができる． $5 \mathrm{tf}(49 \mathrm{kN})$ の 荷重は, 車両がレールの継目部を通過するときに生じる 衝撃を考慮したものであるが, 継目落のある場合, また は継目板がゆるんでいる場合には，さらに大きな衝撃の 加わることが考えられる. 正弦波絽り返し荷重の最小值 は 0 としたかったのであるが, 試験機の構造上不可能で あったので $0.6 \mathrm{tf}(5.9 \mathrm{kN})$ とした.

列車が $70 \sim 110 \mathrm{~km} / \mathrm{h}$ で走行するときに, 列車速度を 車輪間隔 $2.1 \mathrm{~m}$ で割れば $9.3 \sim 14.6 \mathrm{~Hz}$ の振動数に相 当する (表一1). この点に関し, 国鉄七尾線の噴泥箇所 に扮いて, 列車が通過するときの路盤圧の変動を測定し た. 測定にあたっては，数個の土圧計をレール中間部に おけるまくらぎ下 $19 \mathrm{~cm}$ の位置に埋設した，そのときの 一例を図一2 に示した. 図によれば，路盤の受ける圧力 
表一1 列車速度と振動数との関係

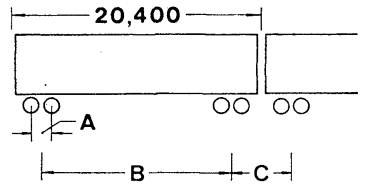

Distance

A: $2,100 \mathrm{~mm}$

B: $14,150 \mathrm{~mm}$

C: $6,100 \mathrm{~mm}$

\begin{tabular}{|c|r|c|c|}
\hline Velocity $(\mathrm{km} / \mathrm{h})$ & \multicolumn{1}{|c|}{ A } & B & C \\
\hline 70 & $9.3 \mathrm{~Hz}$ & $1.4 \mathrm{~Hz}$ & $3.2 \mathrm{~Hz}$ \\
90 & $11.9 \mathrm{~Hz}$ & $1.8 \mathrm{~Hz}$ & $4.1 \mathrm{~Hz}$ \\
110 & $14.6 \mathrm{~Hz}$ & $2.2 \mathrm{~Hz}$ & $5.0 \mathrm{~Hz}$ \\
\hline
\end{tabular}

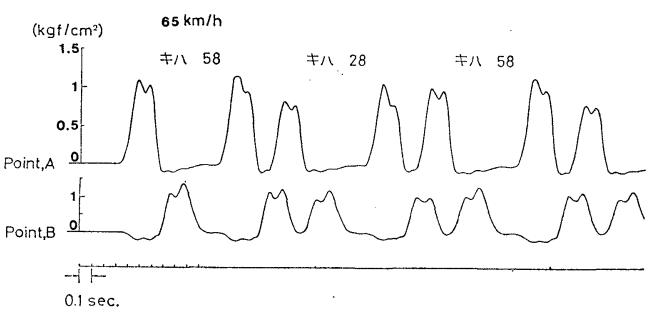

図一2 列車通過時における路盤圧の記録

の変動は 1 つの車輪を 1 個の荷重とみるより，1 台車を 1 個の荷重とみた方が適切であることが示されている.

これはレールおよび道床による荷重分散の効果と考えら れる. したがって本実験では， $0.25 \sim 8 \mathrm{~Hz}$ の各種の振 動数で繰り返し荷重を加えることにした.

c）載荷方法

繰り返し荷重を加える前に, $3 \mathrm{tf}(29.4 \mathrm{kN})$ または 5 $\mathrm{tf}(49 \mathrm{kN})$ の静荷重を 60 分間加えて, その間の沈下の 進行を測定した。しかし，この静荷重試験もいきなり実 施したのではなく，砂袋の圧縮，砂袋と道床砂利との間 および砂利相互の接触を確実にするために 10 分間の予 備載荷を行い，いったん荷重を 0 に戻してこれを出発点 とした.このように, 繰り返し載荷の前に静荷重試験を 行った理由は，繰り返して載荷すること，すなわち，荷 重の変動が道床砂利の圧入に対してどのような効果があ るかを，静的な荷重を加えた場合と比較するためであ る.

静荷重試験が終了した後，続いて繰り返し載荷試験に 移行するには，試験機の構造上ただちに 0.6 ～ $\mathrm{tf}(5.9$ 〜 $29.4 \mathrm{kN})$ ，または 0.6〜 $5 \mathrm{tf}(5.9 \sim 49 \mathrm{kN})$ の振幅とする ことはできず，それぞれの中央の荷重より振幅をしだい に増加させた．この間に約 10 秒を要した。したがって， 繰り返し載荷に移行してから 10 秒後を繰り返し載荷試 験の出発点とした。

\section{（2）試料の性質}

実験には石川県珠洲, 羽咋および辰口地区より採取し た試料を用いた。これらの試料を十分に空気乾燥させた

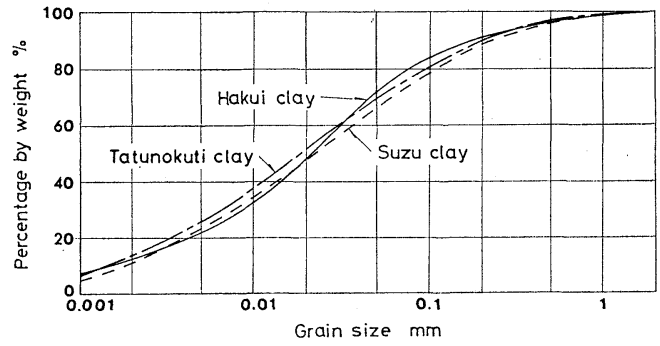

図一3 粒径加積曲線

表一2 試料の物理的性質

\begin{tabular}{|c|c|c|c|}
\hline & Suzu clay & Hakui clay & $\begin{array}{c}\text { Tatunokuti } \\
\text { clay }\end{array}$ \\
\hline Specific gravity & 2.22 & 2.66 & 2.68 \\
\hline Uniformity coefficient & 20.6 & 19.6 & 20.0 \\
\hline Liquid limit & $158 \%$ & $75 \%$ & $53 \%$ \\
\hline Plastic limit & $88 \%$ & $42 \%$ & $36 \%$ \\
\hline Coefficient of permeability & $\begin{array}{c}2.46 \times 10^{-6} \\
\mathrm{~cm} / \mathrm{s}\end{array}$ & $\begin{array}{c}4.49 \times 10^{-7} \\
\mathrm{~cm} / \mathrm{s}\end{array}$ & $\begin{array}{c}4.76 \times 10^{-7} \\
\mathrm{~cm} / \mathrm{s}\end{array}$ \\
\hline Unified soil classification & $\mathrm{MH}$ & $\mathrm{CH}$ & $\mathrm{MH}$ \\
\hline
\end{tabular}

表一3 変水位透水試験における試料の状態（試験前）

\begin{tabular}{l|r|r|c}
\hline & Suzu clay & Hakui clay & $\begin{array}{c}\text { Tatunokuti } \\
\text { clay }\end{array}$ \\
\cline { 2 - 4 } Moisture content (\%) & 160.9 & 60.4 & 50.4 \\
Dry density $\left(\mathrm{kg} / \mathrm{m}^{8}\right)$ & 480 & 1010 & 1131 \\
Void ratio & 3.63 & 1.64 & 1.37 \\
Degree of saturation (\%) & 98.6 & 97.9 & 98.7 \\
\hline
\end{tabular}

後，ロスアンゼルス摩耗試験機で破砕し，ふるいを用い て粒径 $2 \mathrm{~mm}$ 以下とした. 各試料の粒径加積曲線を図一 3 に, 物理的性質を表一2 に示した. なお，各試料の透 水係数は変水位透水試験 (JIS A 1218) を行って求めた. このときの各試料の状態を表一3 に示した. 図一3 によ れば，各試料の粒度分布はほぼ一致しており，いずれも 粘土分を $20 \%$ 以上，シル卜分を $50 \%$ 以上含んでいる. 各試料の粒度分布, 液性限界および塑性指数は鉄道技術 研究所で示唆した噴泥を生じないための必要条件 ${ }^{1,2)}$,

（i） $0.42 \mathrm{~mm}$ ふるいの通過重量百分率が $70 \%$ 以下 であること。

(ii) $0.074 \mathrm{~mm}$ ふるいと $0.42 \mathrm{~mm}$ ふるいの通過重 量百分率の比が 0.65 以下であること.

（iii） 液性限界が $35 \%$ 以下であること.

(iv) 塑性指数が 9 以下であること. を一つも満足せず，きわめて噴泥しやすい土であること を示している．統一土質分類によれば珠洲産および辰口 産粘土は $\mathrm{MH}$ ，羽咋産粘土は $\mathrm{CH}$ となるが，珠洲産粘 土の比重が小さく，液性限界や塑性限界が高いことに注 目される. 市川らの研究 ${ }^{17}$ によれば，この粘土は珠藻土 とよばれ，珪藻の遺骸を含み，きわめて多孔質の土とさ れている。

実験にあたっては，粉末状の試料の気乾状態における 
表一4 試験開始時における粘土層の状態

\begin{tabular}{l|c|c|c}
\hline & Suzu clay & Hakui clay & $\begin{array}{c}\text { Tatunokuti } \\
\text { clay }\end{array}$ \\
\hline Moisture content $(\%)$ & $131.2 \sim 175.6$ & $49.2 \sim 71.6$ & $39.0 \sim 51.3$ \\
Liquidity index & $0.62 \sim 1.25$ & $0.22 \sim 0.90$ & $0.18 \sim 0.90$ \\
Dry density $\left(\mathrm{kg} / \mathrm{m}^{3}\right)$ & $454 \sim 493$ & $983 \sim 1028$ & $1125 \sim 1132$ \\
Void ratio & $3.90 \sim 3.56$ & $1.70 \sim 1.59$ & $1.38 \sim 1.37$ \\
Degree of saturation $(\%)$ & $79.2 \sim 100$ & $78.7 \sim 100$ & $76.2 \sim 100$ \\
\hline
\end{tabular}

含水比を測定し, 適量の水を加えてよく練り混ぜ, 種々 の含水比の粘土試料を作った.このよらにして作製した 粘土試料を, 図一1 に示した円筒容器に突き棒を用いて 大きな空隚を残さないように注意深く詰めた. このとき の含水比, 液性指数, 乾燥密度, 間隙比および飽和度の 変動範囲を表一4 に示した. この表に示したように, 羽 咋産および辰口産粘土に対しては含水比を塑性限界から 液性限界の間で種々変動し, 珠洲産粘土に対しては液性 限界を挟んでその上下に変動した. 乾燥密度については その変動範囲が非常に小さく, 羽咋産粘土では平均值の 上下 $2.2 \%$ 以内, 辰口産粘土では $0.3 \%$ 以内となった. 同一の含水比対して乾燥密度をこれより小さくするた めには, 円筒容器に粘土を詰めるときの突き固めの回数 を減らすことになるが，その場合粘土層中に大きな空隙 の点在するおそれを生じる. また突き棒では粘土が側方 に流動するだけで, これ以上乾燥密度を大きくすること が望まれないので, この場合には粘土層の表面に蓋をし て大きな圧力を加える必要がある.しかし, 実際の噴泥 現象に掞いては, ほぼ等しい列車荷重が繰り返して加わ るので, 当初に大きな荷重を加えて乾燥密度を大きくし てから繰り返し載荷を行ら意義も少ないと考えられる. 含水比の低い場合には乾燥密度を変化させることも可能 と思われるが, 今回の実験においては含水比が比較的に 高いため, 乾燥密度の影響については実験項目として取 り入れなかった。

図一4に含水比と飽和度との関係を示したが, 含水比 と飽和度との関係は直線に近い 1 本の線上にのることが 認められる。

道床砂利としては, 石川県手取川産の粒径 40 70 mm

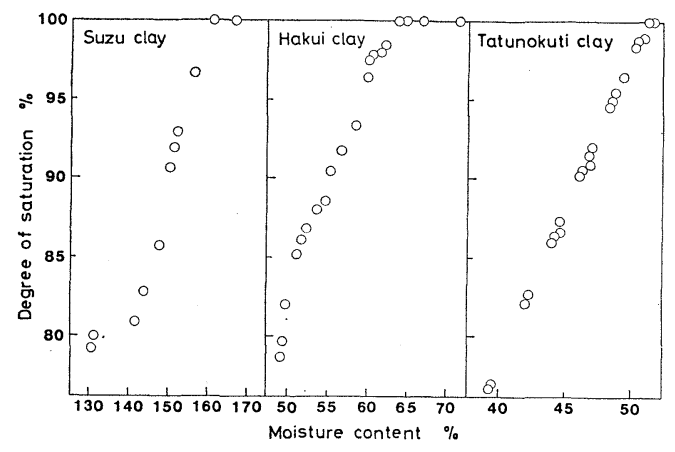

図一4 含水比と飽和度との関係
の砕石を用いた. 実験では, この砕石を粘土層の上に入 念に積み重ねたのであるが，そのときの砂利層の間隚率 は 43\% になっていた. 砂利の中には, 静荷重または繰 り返し荷重を加えている間に割れるものもまれにはあっ たが，大部分は無傷であった。

\section{3. 試験 結果}

\section{（1）静荷重試験}

図一5 7 は, 種々の含水比に調整した粘土に, $3 \mathrm{tf}$ $(29.4 \mathrm{kN})$ の静荷重を加えたときの経過時間と道床面沈 下の進行との関係を, 片対数方眼紙により示したもので ある.これらの図より，沈下の進行は含水比の増加によ って大きくなり, 経過時間の対数に比例するというよ り，いくらか上向きの曲線となることが認められる. 図一8 は，荷重を $5 \mathrm{tf}(49 \mathrm{kN})$ とした場合であるが， 3

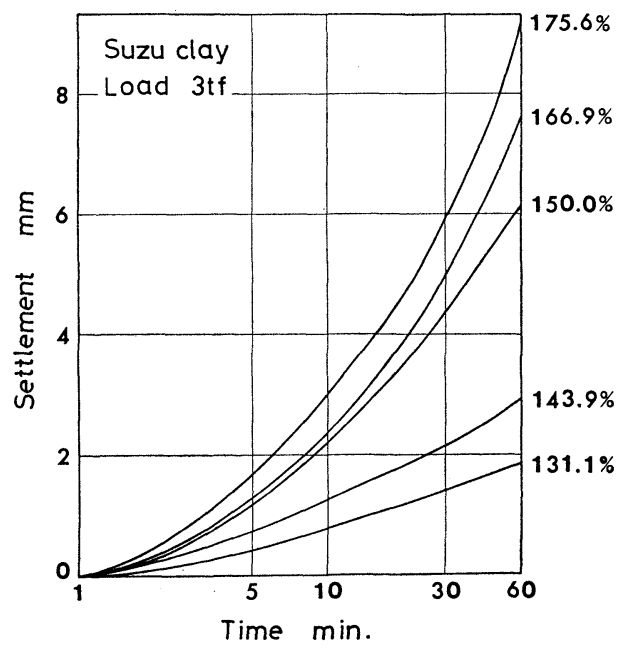

図一5 静荷重による道床面沈下（珠洲産粘土）

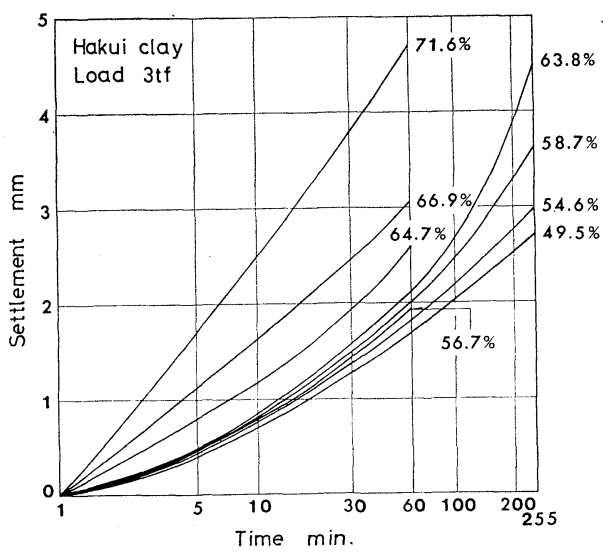

図一6 静荷重による道床面沈下（羽咋産粘土） 


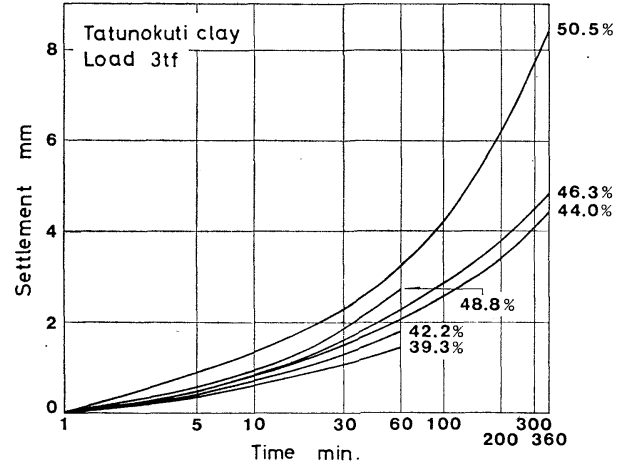

図一7静荷重による道床面沈下（辰口産粘土）

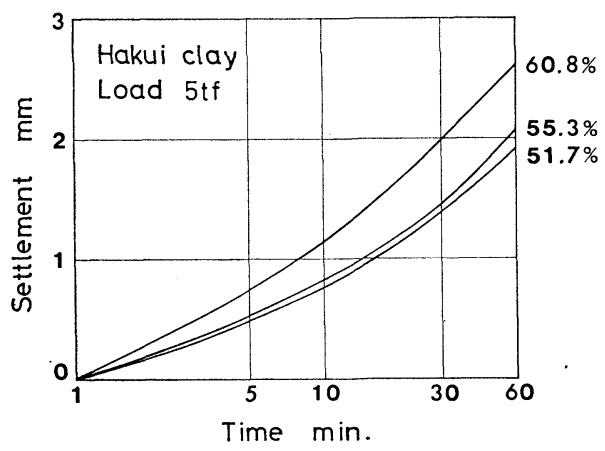

図一8＼cjkstart静荷重による道床面沈下（羽咋産粘土）

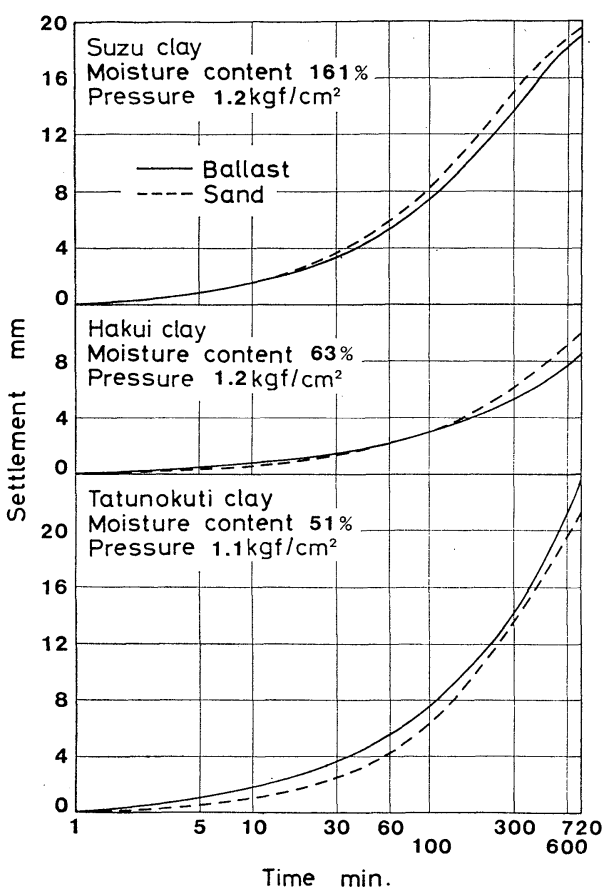

図一9静荷重による道床面沈下

$\operatorname{tf}(29.4 \mathrm{kN})$ の場合（図一6）之比較していくらか進行が 大きい.しかし，荷重の大きさに比例するといらほどで もない.
この沈下量は, 主として粘土層の圧縮または圧密と道 床砂利の圧入よりなると考えられるが, 静荷重を 6 時間 加えたあとの粘土層の状態としては, 試験前粘土層の表 面に置いた砂利がいくらか圧入されていた.しかし，こ の圧入が, 予備載荷の開始の段階で生じたものか, 静荷 重を加えている間に継続して進行したものなのか明らか でない.このことを検討するために, 練り混ぜたときの 飽和度がほぼ $100 \%$ の粘土層の上に, 砂を $20 \mathrm{~cm}$ の厚さ に置いて静荷重を加えた. 同様にして, 砂利を詰めた場 合にも等しい圧力を加えて沈下の進行を比較した. 図一 9 に, 静荷重を 12 時間加えたときの測定結果を示した. 図一9より, 道床面の沈下は, 砂の場合と砂利の場合で ほぼ同様に進行し, したがって静荷重においては, 道床 砂利はほとんど圧入されないことが判明した.

\section{（2）繰り返し載荷試験}

a）繰り返し回数と沈下量との関係

含水比のほぼ等しい珠洲産粘土に, $3 \mathrm{tf}(29.4 \mathrm{kN})$ の 静荷重を 60 分間加えた後, $0.6 \sim 3 \mathrm{tf}(5.9 \sim 29.4 \mathrm{kN})$ の繰り返し荷重を一方には $0.25 \mathrm{~Hz}$ で, 他方へは $1 \mathrm{~Hz}$ で加えたときの道床面沈下の進行を図一10 に示した. この図においては, 静荷重を加えている間の時間の経 過, および繰り返し載荷 50 回までは普通目盛で示し, 50 回以上については対数目盛で示されている. 図一10 より, 道床面の沈下は, 静荷重から繰り返し荷重に移行 することによって急速に進行し, 繰り返し回数の対数に 直線的というより，いくらか上向きの曲線となって進行 することが認められる.また，同一の繰り返し回数に対 しては, 振動数の低いときに進行の大きいことが示され る.

上に述べた振動数の影響を検討するために, 珠洲産粘 土に $3 \mathrm{tf}(29.4 \mathrm{kN})$ の静荷重を 60 分間加えた後, 0.6 $3 \mathrm{tf}(5.9 \sim 29.4 \mathrm{kN})$ の繰り返し荷重を各種の振動数で それぞれ同一の回数ずつ加えたときの道床面の沈下を測 定した.その一例を図一11 に示した。最初の 1000 回 は $4 \mathrm{~Hz}$ で加え, 次の 1000 回は $2 \mathrm{~Hz}$ とし,このよう に振動数を順次低くしたときの沈下の進行を普通目盛で

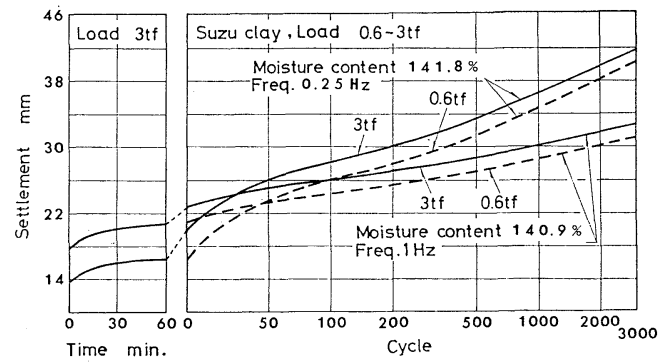

図一10 静荷重および繰り返し荷重による道床面沈下 （珠洲産粘土） 


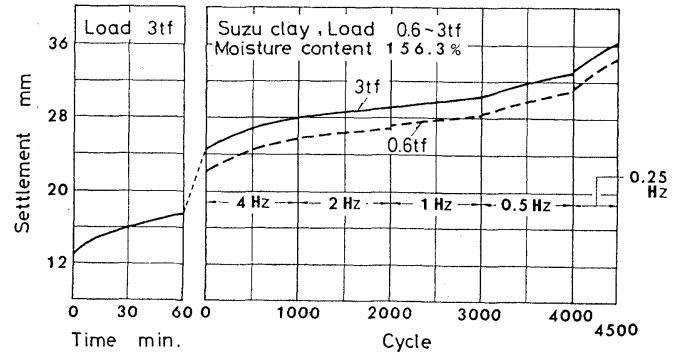

図一11静荷重および繰り返し荷重による道床面沈下 （珠洲産粘土）

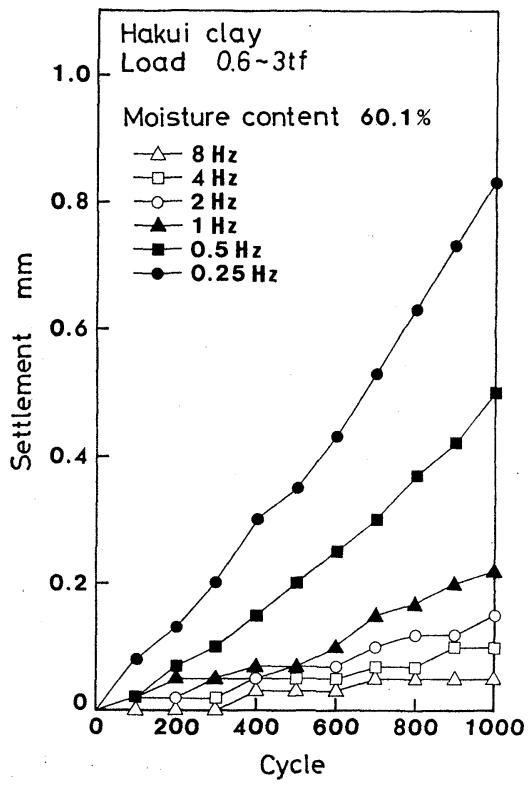

図一12 各種の振動数で 1000 回の綝り返し荷重を 加えたときの道床面沈下（羽咋産粘土）

示したものである. 図より, $2 \sim 0.25 \mathrm{~Hz}$ に対しては, 振動数が減少することによって荷重の変動 1 回当たりの 沈下の進行が大きくなることが示される．しかしなが ら, 繰り返し載荷に移行した当初は, 振動数の比較的高 い場合でも急速な沈下の進行を生じ，振動数の影響が明 らかでない。

羽咋産および辰口産粘土に対しては， $3 \mathrm{tf}(29.4 \mathrm{kN})$ の静荷重を 60 分間, 続いて $0.6 \sim 3 \mathrm{tf}(5.9 \sim 29.4 \mathrm{kN})$ の繰り返し荷重を $8 \mathrm{~Hz}$ で 60 分間加えた後に, $8,4,2$, $1 ， 0.5,0.25 \mathrm{~Hz}$ の順にそれぞれ 1000 回ずつ荷重を加 えた. その数例を図一12,13 に示した. また，図一14 には $5 \mathrm{tf}(49 \mathrm{kN})$ の静荷重，および $0.6 〜 5 \mathrm{tf}(5.9 \sim 49$ $\mathrm{kN})$ の繰り返し荷重を $4 \mathrm{~Hz}$ で加えた後に，4，2，1， $0.5,0.25 \mathrm{~Hz}$ の順に加えた場合を示した.これらの図よ り, 同一の繰り返し回数における沈下の進行は, 振動数 の低いとき，すなわち繰り返し 1 回当たりの載荷時閒の 長いときに増大することが確認された。

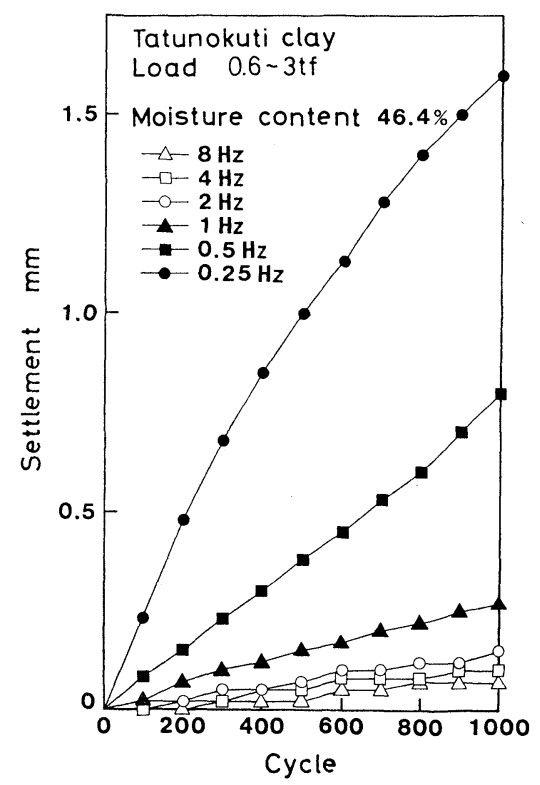

図一13各種の振動数で 1000 回の繰り返し荷重を 加えたときの道床面沈下（辰口産粘土）

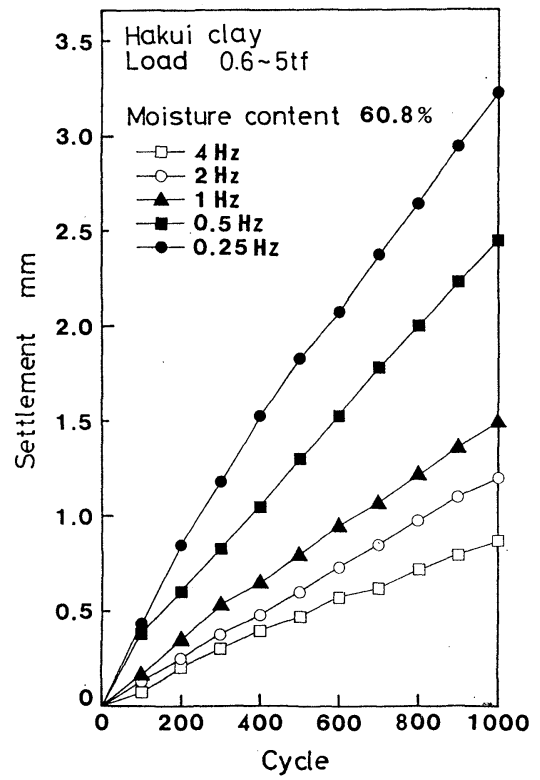

図一14各種の振動数で 1000 回の繰り返し荷重を 加えたときの道床面沈下 (羽咋産粘土)

このような実験を種々の含水比の粘土について実施し たのであるが,羽咋産粘土に対して各種の振動数で 1000 回ずつ繰り返し荷重を加えたときの沈下量の累積を図一 15, 16 に示した. 図一15 は荷重の変動を $0.6 \sim 3$ tf $(5.9$ $\sim 29.4 \mathrm{kN})$ とした場合, 図一16 は $0.6 \sim 5 \mathrm{tf}(5.9 \sim 49$ kN）とした場合である.図一15 によれば，道床面沈下 の進行は, 振動数のほかに粘土層の含水比が大きな関連 をもち, 特に含水比が $62 \%$ （飽和度 $100 \%$, 液性指数 


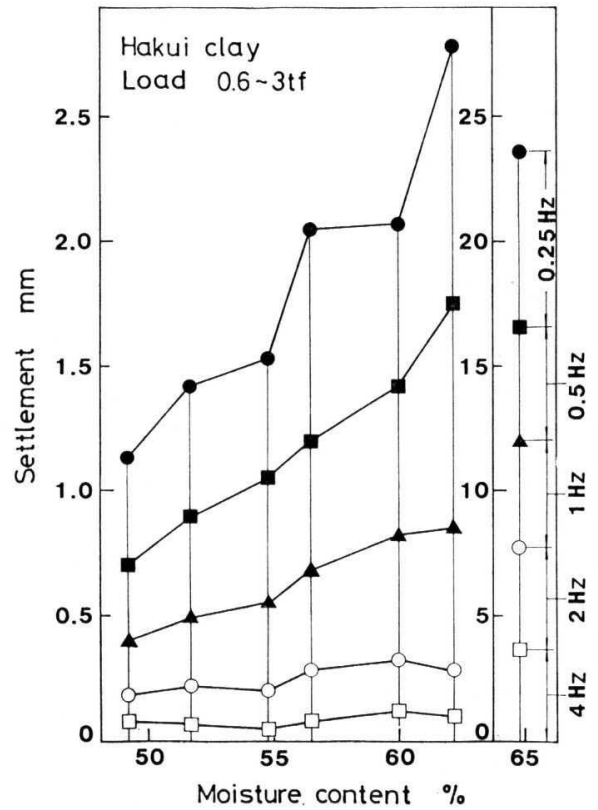

図一15 各種の振動数で 1000 回の繰り返し荷重を加えた ときの道床面沈下の累積 (羽咋産粘土)

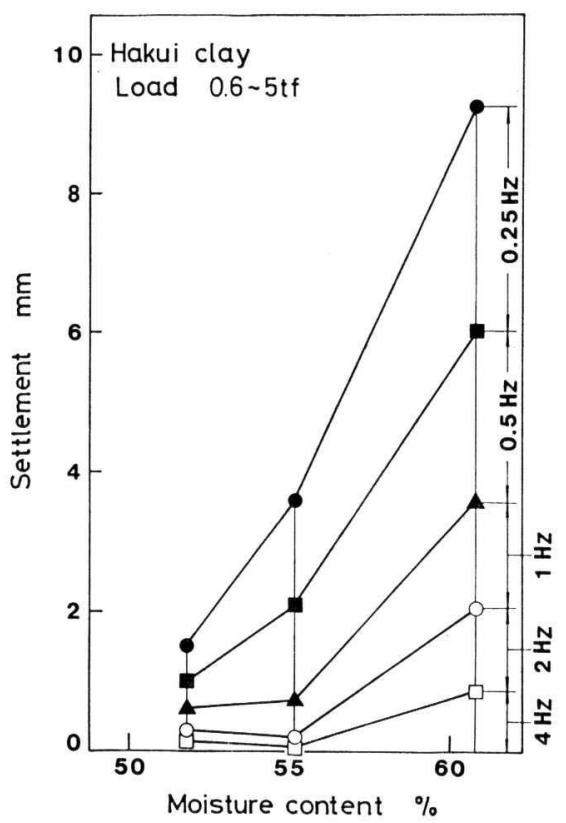

図一16 各種の振動数で 1000 回の繰り返し荷重を加えた ときの道床面沈下の累積（羽咋産粘土）

0.61）を越えると，振動数の高い場合にも急速な沈下を 生じている. 図一15 と 16 を比較して，含水比が $52 \%$ 以下では沈下の進行に大きな差はないが，55\%（飽和度 90\%, 液性指数 0.40）に達すると, 荷重変動の大きさが 沈下の進行に䫓著な影響を与えることが認められる.

次に, 繰り返し回数と道床面沈下の進行との関係を検 討するために，種々の含水比の羽咋産および辰口産粘土

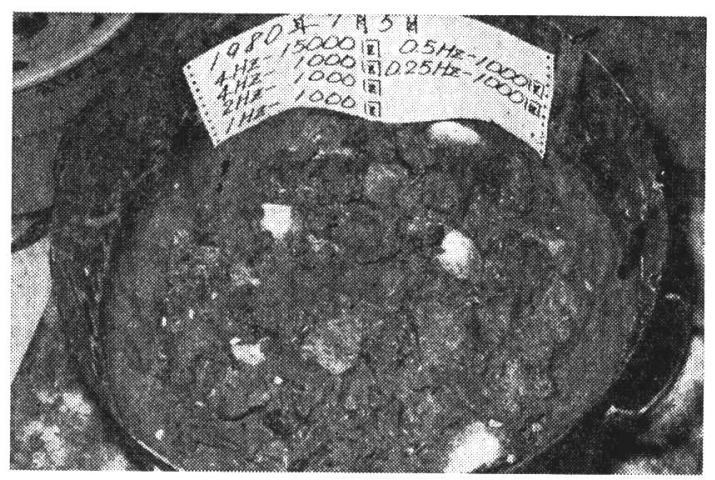

写真一2 試験終了後における砕石の圧入状態

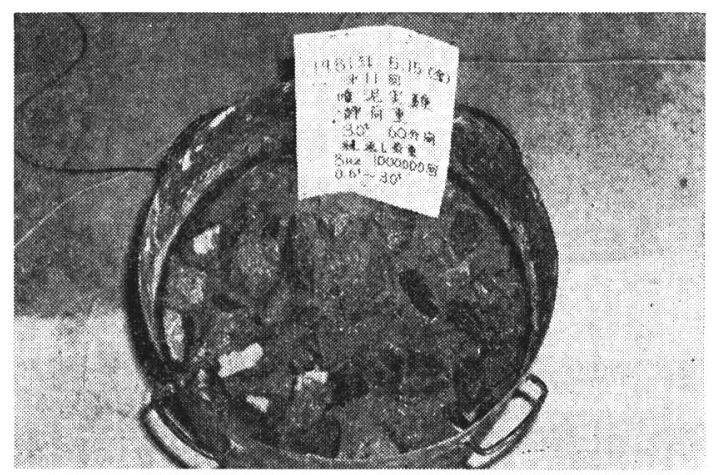

写真一3試験終了後における砕石の圧入状態

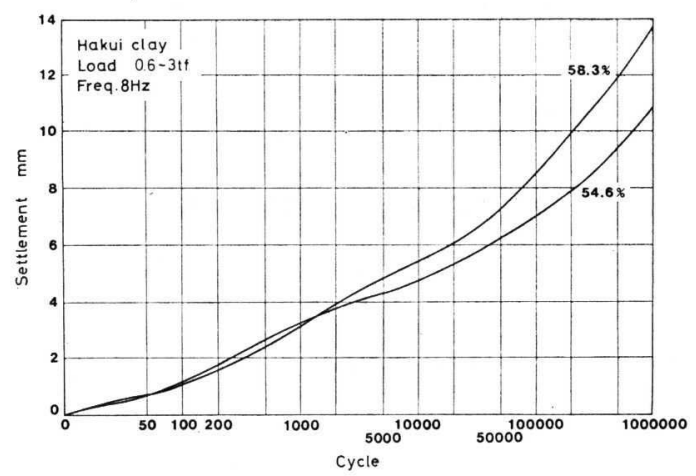

図一17繰り返し荷重による道床面沈下（羽咋産粘士）

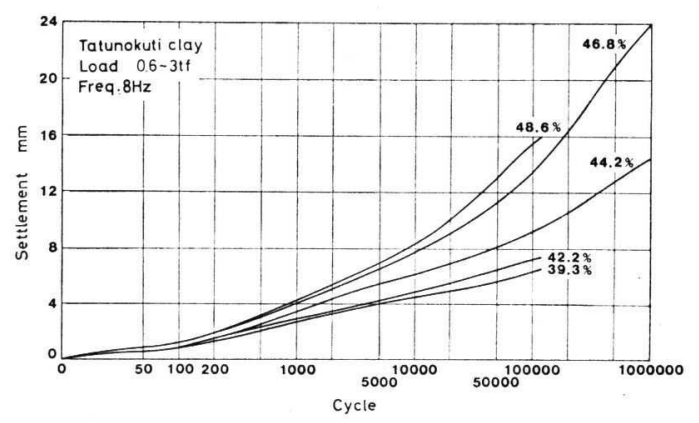

図一18 繰り返し荷重による道床面沈下（辰口産粘士） 
に対して, $3 \mathrm{tf}(29.4 \mathrm{kN})$ の静荷重を 60 分間加えた後 に, $0.6 \sim 3 \mathrm{tf}(5.9 \sim 29.4 \mathrm{kN})$ の繰り返し荷重を 60000 回から 1000000 回加えたときの沈下を測定した. 実験 終了後には, 順次砕石を掘り出して砕石の圧入状態を調 べた. 写真一2，3 に実験終了後における粘土層表面の 状態を示したが，このように砕石が哚く圧入されること は, 静荷重試験ではみられないことであった. $8 \mathrm{~Hz}$ で 繰り返し荷重を加えた場合の沈下の進行を図一17, 18 に，4 Hz の場合を図一19 に示した.これらの図におい て, 繰り返し載荷 50 回までは普通目盛, 50 回以上は対 数目盛で示してある．繰り返し回数が比較的に少ない間 は, 繰り返し回数の対数と沈下量との間にはほぼ直線的 な関係が認められる.しかしながら, 回数が増すにつれ て，沈下の進行はしだいに上向きの曲線を示している. また，図一18 と図一19 に扔いて，ほぼ等しい含水比で それぞれ 500000 回での沈下量を比較すれば， $4 \mathrm{~Hz}$ で 繰り返し荷重を加えた場合は $8 \mathrm{~Hz}$ の場合より 20〜30\%

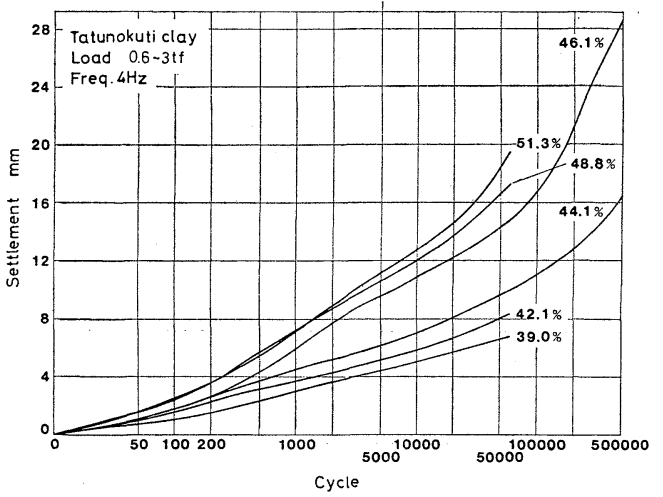

図一19 繰り返し荷重による道床面沈下（辰口産粘土）

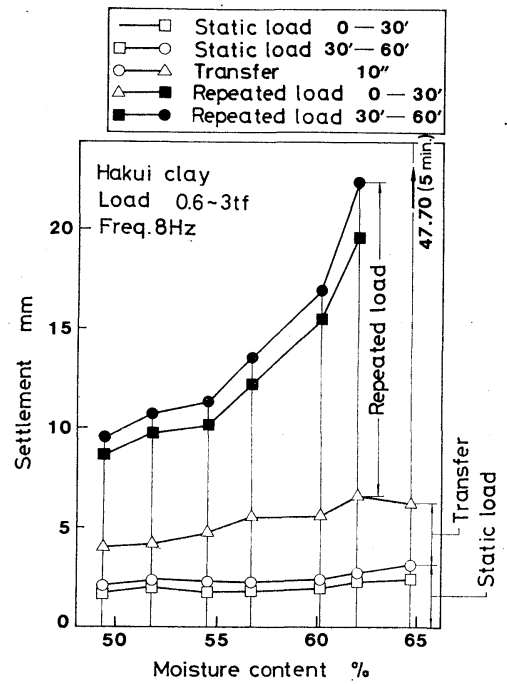

図一20 静荷重および繰り返し荷重による道休面沈下 の累積 (羽咋産粘土)
大きい，このように，繰り返し回数を多くした場合にも 振動数の低いときに沈下の進行が大きいことは,さきの 図一10〜16 に示した測定結果と一致している.

b）繰り返し載荷時間と沈下量との関係

静的載荷に比べて，繰り返し載荷が道床面の沈下にど のような効果をもつかを知るために，種々の含水比の粘 土に, 静荷重を 60 分加えている間の沈下と, これに続 いて繰り返し荷重を 60 分加えた間の沈下を比較した. 図一20 22 に，羽咋産粘土に扔ける測定結果を示した。 図において, Transfer と記入した部分は, 静荷重から 繰り返し荷重に移行するために，荷重変動の振幅をしだ 、に増加した過程を示す. 図一20 22 は，それぞれ 8, $4,2 \mathrm{~Hz}$ の場合であるが，いずれも静荷重を加えたとき の沈下量は少なく，含水比の影響もわずかである．それ

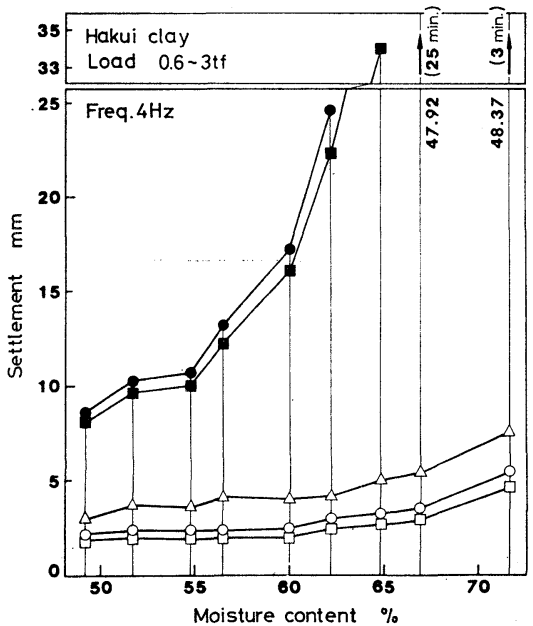

図一21静荷重および繰り返し荷重による道床面沈下 の累積（羽咋産粘土）

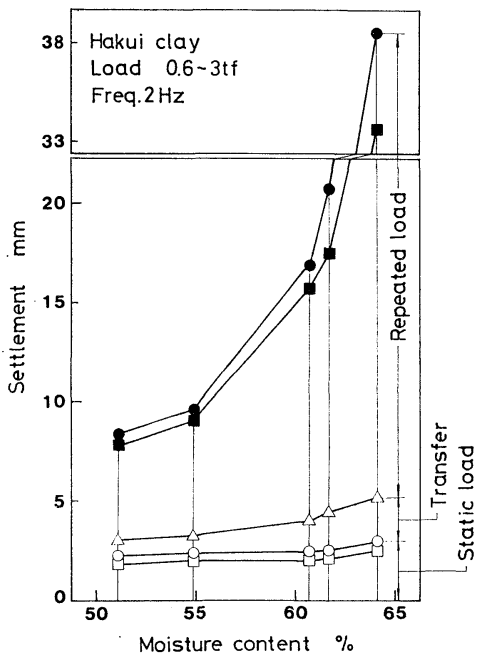

図一22 静荷重および繰り返し荷重による道床面沈下 の累積（羽咋産粘土） 
に対して, 繰り返し荷重においては, 含水比の増加によ る沈下量の増加が明らかに認められ，特に含水比が $62 \%$ （飽和度 $100 \%$, 液性指数 0.61 ）を越えると沈下の進行 は急速となる. また, 含水比の高い場合には, 繰り返し 載荷 60 分間の沈下量が, 静的載荷 60 分間の沈下量の 10 倍以上となっている.

これらの測定結果に基づき, 種々の含水比の粘土に各 種の振動数で繰り返し荷重を 60 分間加えたときの沈下

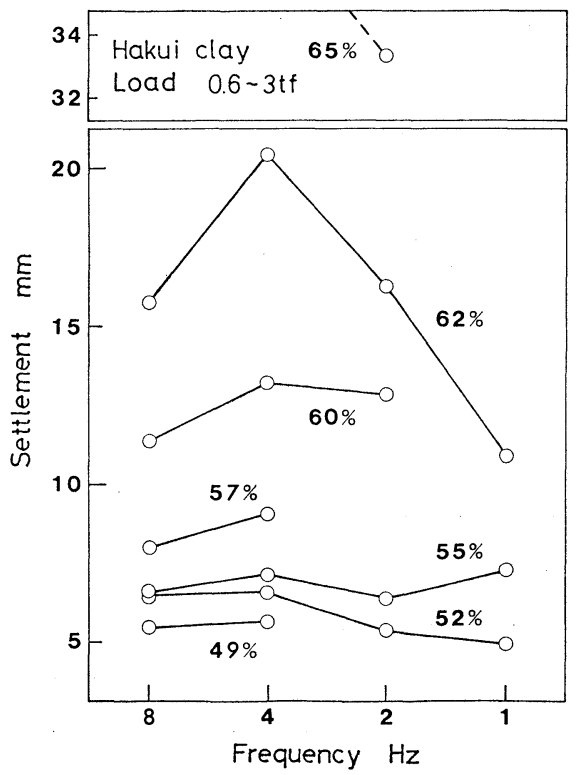

図一23 繰り返し荷重を 60 分間加えたときの道床面沈下 （振動数と沈下量との関係一羽咋産粘土）

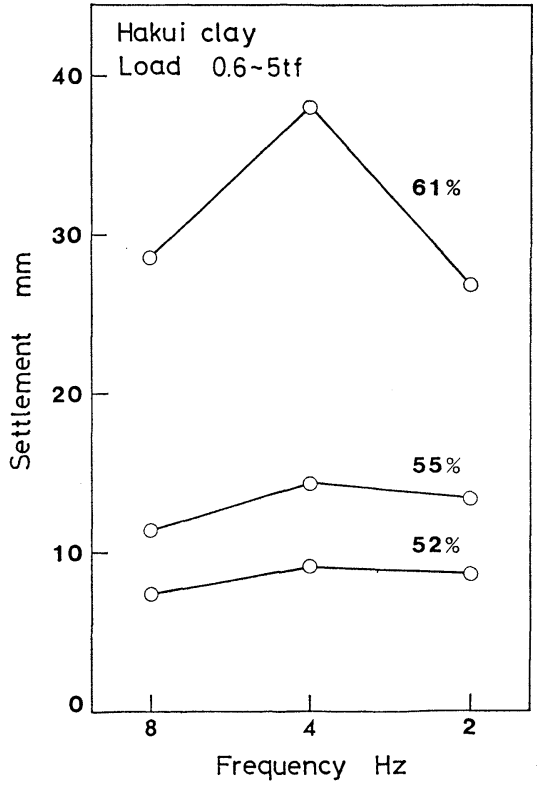

図一24 繰り返し荷重を 60 分間加えたときの道床面沈下 （振動数と沈下量との関係一羽咋産粘土）
量の比較を 図一23〜25 に示した. 図一23 は, 羽咋産粘 土に $0.6 \sim 3 \mathrm{tf}(5.9 \sim 29.4 \mathrm{kN})$ の繰り返し荷重を加えた 場合であるが，含水比の低い場合には，同一の載荷時間 における沈下量は振動数によって大きな変化のないこと が示されている.しかし，含水比が $55 \%$ （飽和度 $90 \%$, 液性指数 0.40 )を越えると，いずれの振動数においても 沈下量は急に増加し, 特に $4 \mathrm{~Hz}$ で著しい. 図一24 には 荷重変動の大きさを $0.6 \sim 5 \mathrm{tf}(5.9 \sim 49 \mathrm{kN})$ とした場合 を示した. 図一23 と比較して，沈下量は含水比が $52 \%$ のときには $1.2 \sim 1.6$ 倍となり, 荷重の大きさにほぼ比

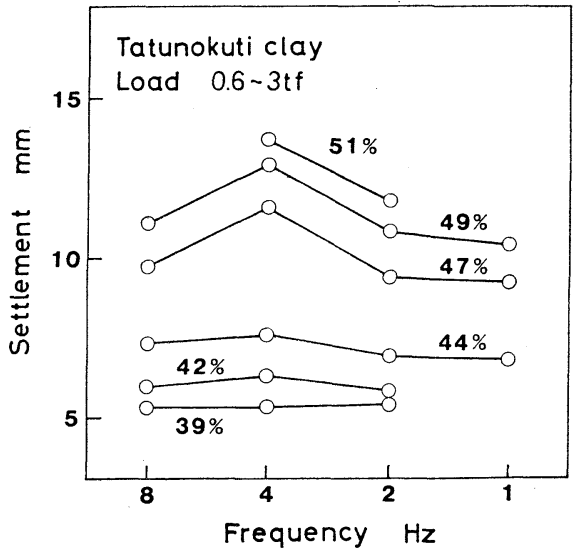

图一25繰り返し荷重を 60 分間加えたときの道床面沈下 （振動数と沈下量との関係一辰口産粘土）

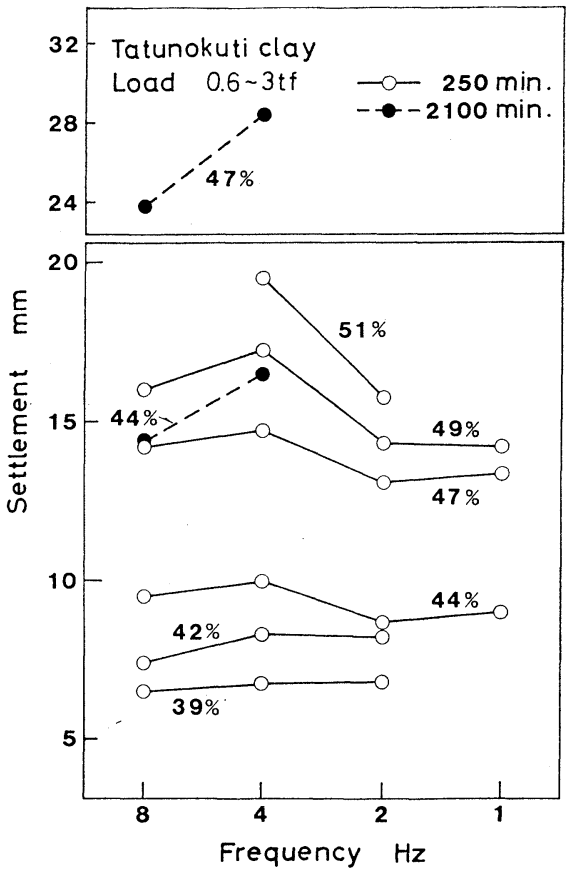

図一26 繰り返し荷重を 250 分または 2100 分間 加えたともの道床面沈下（振動数と沈下 量との関係一辰口産粘士） 
例して増加する．しかしながら，含水比が $55 \%$ (飽和度 90\%, 液性指数 0.40 ）を越えると 1.7〜2.9 倍となり, 荷重の大きさに比例するというよりそれ以上に増加する ことが認められた. 図一25 は辰口産粘土の測定結果で あるが，この粘土においても含水比が $44 \%$ ，すなわち， 飽和度が $90 \%$ (液性指数 0.47 ) を越えると沈下量は急 に増加し, $4 \mathrm{~Hz}$ のときに最大となることがわかる. 図一 26 は, 繰り返し荷重を 250 分間, または 2100 分間加 えた場合であるが, この図からも道床砂利の圧入を生じ やすい振動数, または含水比の存在することが明らかに 認められる。

以上の内容を詳細に 検討した結果, 飽和度が $90 \%$, または液性指数が $0.4 \sim 0.5$ を越えると, $4 \mathrm{~Hz}$ において は当初の 10 分間に打ける沈下の進行が特に大きくなっ ていることが判明した。

\section{4. 考察}

本研究に扔いては，噴泥によって生じる道床面の沈下 を検討するために，種々の条件のもとで多数の実験を行 った。しかし，そこで測定された沈下量の中には，道床 砂利が粘土層に圧入される量や粘土層の圧縮, または圧 密量のほかに, 砂利層の圧縮量が含まれる抢それがあ る.このことを検討するために, 円筒容器の底部に 5 $\mathrm{cm}$ の砂層を置き，その上に 10,20 または $30 \mathrm{~cm}$ の砂 利層を置いて荷重を加えた。まず, $3 \mathrm{tf}(29.4 \mathrm{kN})$ で 10 分間の予備載荷を行い, 次に $3 \mathrm{tf}(29.4 \mathrm{kN})$ の静荷重を 30 分間, 続いて 0.6 3 tf $(5.9 \sim 29.4 \mathrm{kN})$ の繰り返し荷 重を $4 \mathrm{~Hz}$ で 8000 回加えた.このときの結果を図一27, 28 に示した. これらの図によれば, 静荷重による道床 面の沈下はきわめてわずかであるのに対し, 繰り返し荷 重を加えたときには約 $7 \mathrm{~mm}$ の沈下を生じている. しか しながら, この沈下量は, 主として道床砂利が下の砂層 一圧入された量であると推定される. その理由として は, 図一27, 28 に示すように, 沈下量は砂利層の厚さ にほとんど関連をもたない，もし，道床内の空隚が圧縮 されるのであれば，沈下量は砂利層の厚さに比例するは ずである. 以上の測定結果より，これまでの実験で得ら れた道床面の沈下量の中には, 砂利層の圧縮量は含まれ ないとみなせる.

一般に繰り返し荷重によって生じる沈下量 $S$ は, 道 床砂利の圧入量 $y$ と粘土層の圧縮, または圧密量 $C$ 上 りなるが，砂利層の間幥率を $n$ とし，粘土が砂利層中を 上昇した高さを $r$ とすれば, 次の関係が成り立つ.

$$
\begin{aligned}
& y=n \cdot r \cdots . \\
& S=y+C .
\end{aligned}
$$

上式において $r$ を正確に測定することは困難である

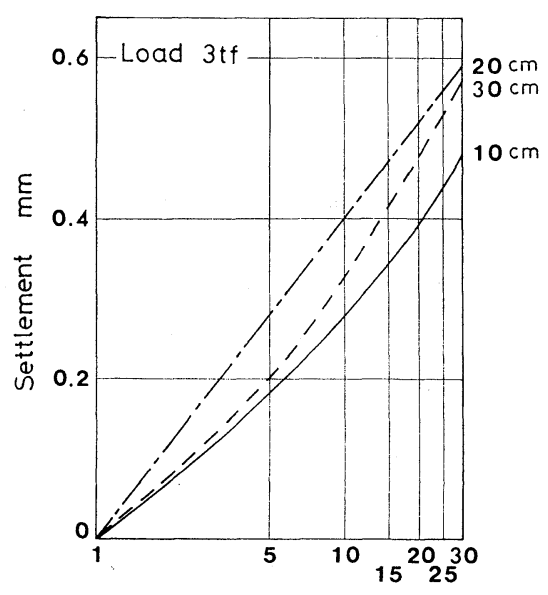

Time $\mathrm{min}$.

図一-27 静荷重による砂利層の沈下

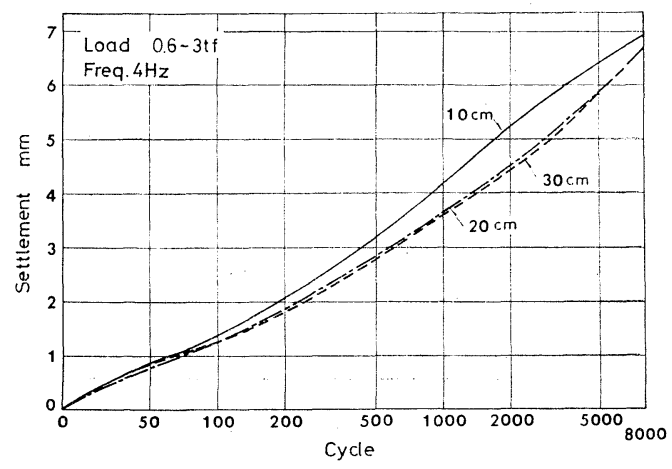

図一28繰り返し荷重による砂利層の沈下

が, 繰返しり載荷試終験了後, 粘土層に圧入された砕石 を掘り出して $r$ の概略值を測り $n=0.43$ として $y$ を 求めた結果, $S$ とほぼ一致した. したがって, 繰り返し 荷重を加えたときに道床面が沈下する主な要因として は，道床砂利の粘土層への圧入ということになる. 特 に, 羽咋産粘土の実験においては, 道床面の沈下が 30 $\mathrm{mm}$ 以上となった場合もあったが，上式より，そのとき の粘土の上昇高さは $70 \mathrm{~mm}$ となる.実際の鉄道線路に おいて, 繰り返し回数がさらに増加すれば, 粘土がまく らぎ下面にまで到達することが当然考えられる.

測定の結果, 道床面の沈下は, 繰り返しの振動数と関 連し, 繰り返し載荷 1 回当たりの沈下の進行は振動数の 低いときほど大きい。一方, 同一の載荷時間に対して は, $4 \mathrm{~Hz}$ の場合の沈下が最大となる. 前述のように, 1 台車の通過によって路盤は 1 回の圧力変動を受けている ので, 実際の線路においては, $4 \mathrm{~Hz}$ 付近の圧力変動を 受ける可能性が大きい. また, 道床砂利の圧入は, 粘土 層の含水比の影響を大きく受け, 練り混ぜたときの飽和 度が 90\%，または液性指数が $0.4 \sim 0.5$ を越えると著し く進行する.しかし, 本実験における繰り返し載荷は, 
静荷重を 60 分間加えたあとに実施した関係上, 繰り返 し載荷に移行したときの飽和度は, 練り混ぜたときと比 ベていくらか高くなっていると考えられる.

図一1 に示したように, 円筒容器の底部には土圧計を 配置し，また，練り混ぜたときの飽和度がほぼ $100 \%$ の 粘土層には, 間隚水圧計を埋め込んだ. 繰り返し荷重を 加えた場合には, これらの計器の追随性に疑問が残り, 路盤中の圧力, または間隙水圧の変動に関しては, 今後 の研究に扔いて解明したい.

一般に繰り返し載荷に移行してから約 10 分間におけ る道床面沈下の進行は著しく, この間の沈下の進行は, 繰り返し回数の対数と直線的な関係にある. 著者の 1 人 は，かつてこの間の沈下の進行を絽り返し回数の平方根 に比例するとして発表したこともある ${ }^{10): 11)}$. その後の 沈下の進行に関して今回の実験結果を整理したところ, 以下に示すように繰り返し回数のべき関数でほぼ近似で きることが判明した．べき関数の指数と含水比との関連 については, 最小 2 乗法を用いて定めた。

羽咋産粘土

荷重変動の範囲：0.6 3 $\mathrm{tf}(5.9 \sim 29.4 \mathrm{kN})$

$$
S=2.07\left(\frac{N}{F}\right)^{1.0 w-0.39} \text {..... }
$$

$$
\text { ただし, } 0.49<w<0.62
$$

荷重変動の範囲：0.6〜 $5 \mathrm{tf}(5.9 \sim 49 \mathrm{kN})$

$$
\begin{aligned}
& S=2.87\left(\frac{N}{F}\right)^{2.1 w-0.97} \ldots \ldots . . \\
& \text { ただし }, 0.52<w<0.62
\end{aligned}
$$

辰口産粘土

荷重変動の範囲 : 0.6 3 tf $(5.9 \sim 29.4 \mathrm{kN})$

$$
\begin{aligned}
& S=1.35\left(\frac{N}{F}\right)^{1.0 w-0.23} \ldots \ldots . . \\
& \text { ただし, } 0.39<w<0.51
\end{aligned}
$$

上式に扔いて $N$ は繰り返し回数, $F$ は振動数, $w$ は 含水比を表わす.したがって, N/F は経過時間となる.

上式 (3)，(4) に上れば, 羽咋産粘土において含水比 が $53 \%$ のときの指数はいずれも 0.14 となるが，これ より含水比が大きくなれば, 式（4）における指数は式 (3) の指数と比べてしだいに増加していく.式 (3)，(4), (5) より，一般に沈下の進行は繰り返し回数の $0.1 \sim 0.3$ 乗に比例し，この指数は含水比とともに増加することを 示している.また，上式に扔いては，振動数の高いとき に沈下の進行が少なくなることを示し，これは列車速度 の大きいときに相当する. しかし, 列車速度が増加すれ ば，レール面の高低狂いによる荷重の変動が大きくな り，特に，レール継目部に扔ける衝撃は増大する.さら に, レール面や車輪踏面に傷のある場合には静荷重の数 倍の衝撃を加えることがある.これらをあわせて考察す れば, 列車速度の増加に伴って, 道床砂利の圧入も促進
されると考えられる。

\section{5. 砂利の圧入に関する理論的考察}

道床砂利が粘土層中に圧入される過程, または流動性 をもつ粘土が道床中の空隚を上昇する過程に関しては, 粘性流体力学の関与寸る部分が多いと考えられるが，こ こでは簡単な解法を試みる.

道床面に加える荷重を $P_{t}$ とすれば, $P_{t}$ は円筒容器 の壁面と砂利層との間の摩擦力 $P_{f}$, 最下面の䂶石が粘 土層へ圧入するときの抵抗力 $P_{c}$, おょよび道床砂利の間 隚を粘土が上昇するときの抵抗力 $P$ よりなる.

$$
P_{t}=P_{f}+P_{c}+P
$$

実験に扔いて, 繰り返し荷重による砕石の破損はほと んどなかったことにより，試験中における砕石のかみ合 い状態に変化はなく，したがって， $P_{f}$ の大きさは一定 と考えられる．また， $P_{c}$ の大きさは粘土層の含水比の 変動に関連をもつが, 試験前後の含水比にはほとんど変 化が認められなかったので, $P_{c}$ の大きさも一定とみな される．したがって $P_{t}$ の大きさが一定ならば， $P$ もほ ぼ一定に保たれると考えられる.

次に $P$ と道床砂利の圧入量 $y$ との関連について考察 する. 砂利層の間隚率を $n$ とするとき, 粘土は砂利層中 を $y / n$ だけ上昇することを前章に述べた. 道床砂利と粘 土との接触部の面積は， $y / n$ に比例して増加すると考え られるので，これを $b y / n$ とおく．この面がすべて垂直 面ならば, 単位面積に作用する摩摖力は $P /(b y / n)$ とな るが，実際には砂利層における間隚の形状は不規則であ るから, 単位面積に作用する平均摩擦力 $\tau$ は, 上記の值 にある係数 $k$ を掛けた值とする。

$$
\tau=k P /(b y / n) \text {. }
$$

式 (7) によれば， $\tau$ は $y$ に反比例することになる.こ の 活研石に作用する摩擦力であると同時に, 砕石に接 した粘土に作用するせん断力となる。

1 回の荷重変動において道床砂利が圧入される量を $\Delta y$ とするとき, $\Delta y$ と $\tau$ との間には何らかの関係が成 り立つと考えられる. (a) 粘土を流体力学で扱らニュー トン流体と仮定すれば， $\Delta y$ は $\tau$ に比例すると考えられ， また，(b) 粘土と砕石との間のすべり摩擦を固体摩擦と 仮定すれば， $\tau$ がある一定の值を越えると $\Delta y$ は急に増 加する、これを図で表わせば図一29のようになる。こ れらは両極端の場合と考号らるので，(a) と（b)の中 間をとって $\Delta y$ と $\tau$ との関係を次式で表わす.

$$
\Delta y=a \tau^{\lambda}
$$

ここに, 入は 1 より大きな定数とする.

式 (7) を式 (8) に代大すれば,

$$
\Delta y=a(k P)^{2}(b y / n)^{-\lambda}
$$




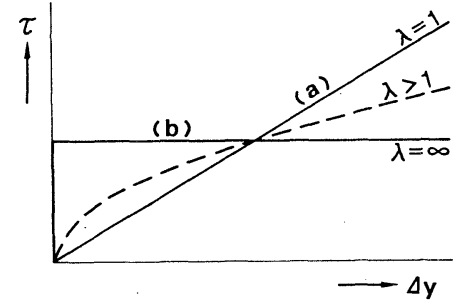

図一29 砕石と粘土との間に作用する摩擦力 と移動量との関係

$y$ は $\Delta y$ の累計であり, また荷重の繰り返し回数を $N$ とすれば,

$$
\Delta y=\frac{d y}{d N}
$$

とおくことができる.したがって，

$$
\frac{d y}{d N}=a(k P)^{\lambda}(b y / n)^{-\lambda}
$$

$N=0$ のとき， $y=0$ になるとして上式を解けば，

$$
y=\left(\frac{k n P}{b}\right)^{\lambda /(\lambda+1)}\{(\lambda+1) a N\}^{1 /(\lambda+1)}
$$

式（5）によれば， $N$ の指数は $0.16 〜 0.28$ の間に変動 するが, 式 (12) の $N$ の指数をこの值に一致させるた めには $\lambda=3 \sim 6$ とする必要がある。また，このときの $P$ の指数は $0.75 \sim 0.86$ となる.

以上に述べた式の誘導においては, 繰り返し荷重の振 動数が考慮されていないが，式 (8)，または式 (9) に相 当する変形に到達するにはある時間の継続を必要とし， 振動数の高いときには, この変形に到達する前に変形の 進行が打ち切られてしまうと考えなくてはならない.

\section{6. 結 論}

本研究に打いては，噴泥による道床面の沈下を検討す るために，物理的性質からみて噴泥の発生が予測された 粘土を使用して，種々の条件のもとに荷重を加えたとき の道床砂利の圧入過程を測定したのであるが，以下に本 研究より得られた成果を要約する.

（1）静的な荷重においては，道床砂利はほとんど圧 入されない.

（2）道床面の沈下は，同一の大きさの荷重を静的に 継続して加えているときより, その荷重を繰り返して加 えたときに著しく進行する。

（3）道休面の沈下は，繰り返しの初期においては， 繰り返し回数の対数に比例するとみることもできるが, 繰り返し回数が増加すれば, 繰り返し回数の $0.1 \sim 0.3$ 乗に比例して進行する.

（4）道床砂利の圧入には, 粘土層の飽和度が大きく 関連し，圧入は飽和度が $90 \%$ を越えると急に増加する。
これは液性指数が $0.4 〜 0.5$ のときに相当する.

（5）同一の繰り返し回数における沈下，すなわち， 繰り返し 1 回当たりの沈下の進行は, 振動数の低いとき ほど大きい。しかし，同一の繰り返し載荷時間に対して は，4 Hz のときに最大となる.

以上に述べたように，粘土層に加わる荷重が変動する ときに初めて道床砂利が圧入されるといらことは, 粘土 層のもつどのような性質と関連するのか今後の研究にお いて解明を続けたい。

謝辞 : 現場調查にあたりご協力をいただいた金沢 鉄道管理局の諸氏，および土質試験に関してご助言をい ただいた金沢工業大学講師前川晴義氏に対し深謝の意を 表します．また実験に協力してくれた金沢工業大学土木 工学科卒業研究生諸君に感謝いたします。

\section{参 考 文 献}

1）西解達夫 : 鉄道の路盤に関する二，三の問題，土と基礎， Vol. 4, No. 6, 1956.

2）西亀達夫：鉄道路盤表層土の材質判定法について，土と 基礎, Vol. 9, No. 3, 1961.

3）西象達夫 : 鉄道線路の噴泥，土と基礎，Vol. 4, No. 1, 1956.

4）西亀達夫・伊東孝之：鉄道の路盤について，土と基礎， Vol. 20, No. 6, 1972.

5）伊東孝之：噴泥対策 と新路盤工，鉄道技術研究資料， Vol. 34, No. 9, 1977.

6）伊能忠敏：鉄道線路に打ける路盤改良の新しい方向，土 木学会誌, Vol. 63, No. 8, 1978.

7）原 繁男： 線路改良のポイント, 鉄道線路, Vol. 28, No. 10,1980 .

8）伊東孝之・岩崎高明・野口達雄 : 噴泥の実態とその対策 (1)，鉄道技術研究報告，No. 1062 (施設編第 472 号), 1977.

9）伊東孝之・岩崎高明・野口達雄・大脇康孝：噴泥の実態 とその対策 (2)，鉄道技術研究報告，No. 1077 (施設編 第 479 号 $), 1978$.

10）小野一良・伊藤義男：軟弱路盤における砂利の圧入過程 について，金沢大学工学部紀要, Vol. 6, No. 4, 1972.

11）小野一良・伊藤義男：軟弱路盤に扔ける砂利の圧入過程, 鉄道線路, Vol. 21, No. 2, 1973.

12）小野一良・山田幹雄：鉄道線路の噴泥に関する研究，土 木学会第 35 回年次学術講演会講演概要集, III-71, 1980 .

13）小野一良・山田幹雄：鉄道線路の噴泥に関する研究（第 2 報), 土木学会中部支部研究発表会講演概要集, IV - 1 , 1981.

14）山田幹雄・小野一良：鉄道線路の噴泥に関する研究（第 3 報), 土木学会第 36 回年次学術講演会講演概要集, III36, 1981.

15）伊能忠敏・伊東孝之・鬼頭 誠・狭田彰二：鉄道路盤の 圧縮沈下実験, 土質工学会第 16 回土質工学研究発表会発 表講演集, $402(\mathrm{H}-6), 1981$.

16）伊能忠敏・伊東孝之・渡辺英男：中型模型による噴泥再 現実験, 土質工学会第 16 回土質工学研究発表会発表講演 集, 405 (H-6), 1981.

17）石川県珪藻士利用研究会基礎部会編：能登産珪藻土の基 礎研究，石川県工業試験場，1966.

(1981.8.22. 受付) 